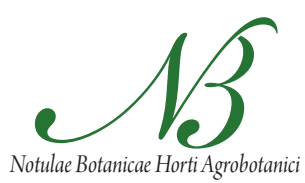

Cluj-Napoca

\title{
Appropriate Methods for Evaluating the Agricultural Policies' Consequences at the Farm Level
}

\author{
Ionel M. JITEA \\ University of Agricultural Sciences and Veterinary Medicine, 3-5 Mănăş̧tur, Cluj-Napoca, Romania; mjitea@usamvcluj.ro
}

\begin{abstract}
The Common Agricultural Policy is foreseen to suffer important reforms after 2013, which will greatly affect the farm's production environment. For the a priori analysis of such policy measures, there was built a recursive single period model adapted to the Romanian farming system. The positive mathematical programming method in use, proved to be in the last period highly applied in agricultural policies impact studies at the European level. Furthermore, the model was employed in order to test three different agricultural scenarios that were proposed by the European Commission as reform alternatives. The first policy option presumes to leave unchanged the current direct payment system while slightly changing the payment distribution pattern among Member States. The second policy option envisages substantial changes of the direct payment system that would be allocated only if farmers bring societal benefits. The last option consists in phasing out direct payments and provides limited financial support to farmers through the second Common Agricultural Policy pillar (rural development). All these options were investigated on the economical and financial data of 21 Romanian farms categorized according to the European classification system as mixed crops livestock farms. Results show that all these policy options have important effects on the farm revenue, in the sense that a decrease in the subsidy level produces important average gross margin falls. Soft landing approach in the first CAP pillar's reform is desirable especially for the Romanian agriculture that still presents important farm structural shortcomings.
\end{abstract}

Keywords: agricultural policy, positive mathematical programming, reform, Romania

\section{Introduction}

The use and the development of mathematical models which can simulate farm functioning have an extremely rich tradition and practice. The general rule consisted of optimising an objective function in a linear programming framework (Hazel and Norton, 1986). Such a technique was applied to farms with different technological specialisations. For instance, horticultural production, due to its importance in the agricultural yields was the appropriate research field over the time. Garry et al. (1998), argue that modelling techniques are suitable for horticulture production due to their feasibility. Moreover, it posed problems when building simulative models that did not know a general accepted solution and which were purely addressed over time such as: the high diversity of the cultivation system; interplant variability; the plant's water balance or the formation of product quality. Lentz (1998) characterised the horticulture production process as being an open and highly complex system, affected by weather, soil, insects, diseases, weeds, nutrition, prices and the interactions between these factors.

Furthermore, modelling techniques have been used in different ways over the time. One application was represented by the evaluation of new management and production techniques. Hester and Cacho (2003) used a dynamic bio economical model to deal with the complex relationship between biological and economical realities from an apple orchard system. Vinten and Dunn (2001) developed a simulating model for the nitrogen cycle in a production system. But, these techniques were highly used in assessing the Common Agricultural Policy (CAP) reform impact at the agricultural sector level. Buysse et al. (2007), Veysset $e t$ al. (2005) chose to build simulative farm models for two farms specialised in animal husbandry production in the first case, or 117 farms specialised in sugar beet production in the second case. Arfini et al. (2001), De Cara et al. (2005) or Judez and De Miguel (2002) employed regional models for assessing the farm's CAP impact. Based on these methodological developments, the paper presents in the next section an economical-mathematical model adapted to the CAP's impact analysis over the Romanian farm production system. It was tested on 21 Romanian farms within different policy scenarios serving as a basis for future empirically investigations.

\section{Material and methods}

The model is based on the hypothesis that the farmer tries to maximise the farm's net income taking into consideration the risk, the physical, the technological and the 
financial production constraints. It is a positive mono periodical recursive one and the optimisation of the production structure has been made over six years, starting with 2010 as reference year. Extending the forecasted period beyond 2016 is difficult, because the conditions of the Romanian's agricultural policy cannot be established for certain.

The first issue which has to be overcome when building such models is that of establishing its activities and constraints. Both field crops (cereals, oil plants, vegetables etc) and cow milk production have been modelled because they are very important for Romanian agriculture and the CAP's reforms are expected to produce consistent macroeconomic changes. Thus, the simulative model, when using " $\mathrm{m}$ " inputs and producing " $\mathrm{n}$ " outputs, in a positive programming framework, becomes:

$$
\max _{x_{i}} \sum_{i=1}^{n}\left[P_{i}\left(\beta_{i}-\delta_{i} x_{i}\right) x_{i}-\sum_{j=1}^{m} \omega_{j} a_{i j} x_{i}\right] \text { (1) }
$$

\section{Subject to :}

$$
A x \leq b \text { and } x \geq 0 ;
$$

where: $\beta_{\mathrm{i}}$ and $\delta_{\mathrm{i}}$ : parameters of the yield function for the "i" output; $\mathrm{P}_{\mathrm{i}}$ : price per "i" output unit; $A: \mathrm{n} \times \mathrm{m}$ matrix with $a_{i j}$ elements representing the necessary input quantity " $j$ " in order to produce an "i" output unit; $x_{i}$ : level of the " $i$ " production; $\omega_{j}$ : average cost for a " $j$ " input unit; $b$ represents the available inputs;

In order to compute the parameters of the yield function (1), the production's shadow prices were calculated. So, the following linear model in which the objective function maximises the farmer's turnover in the reference year can be established (Howitt 1995, 2005):

$$
\max _{x_{i}} \sum_{i=1}^{n}\left(p_{i} \bar{q}_{i}-C M V_{i}\right) x_{i}
$$

\section{Subject to:}

$$
\begin{gathered}
x_{i} \leq x_{i}^{*}+\varepsilon, \forall i=\overline{1, n}\left(\lambda_{2}\right) \\
x_{i} \geq 0 \text { and } \sum_{i} x_{i} \leq \sum_{i} x_{i}^{*}\left(\lambda_{1}\right)
\end{gathered}
$$

where: $\mathrm{i}$ : different production types in the reference year ( $\mathrm{n}$ : their complete number); $\mathrm{p}_{\mathrm{i}}$ : selling price for an " $\mathrm{i}$ " production unit; $\overline{\mathrm{q}}_{\mathrm{i}}$ : average production obtained in the " $i$ " branch in the reference year; $\mathrm{CMV}_{i}$ : variable average cost needed to obtained one " $i$ " production unit; $x_{i}^{*}$ : the employed level of the "i" production type in the reference year; $\varepsilon$ : vector which counts the perturbation of the calibration's constraints (Howitt, 1995). They are chosen in an exogenous manner as small positive numbers, and their use in the model is motivated by the need to prevent the degeneracy problem. The shadow prices of the fixed resources (land in this case $\lambda_{1}$ ) remain in the same time, unaffected by the use of the calibration constraints sets.

Model 2 uses as inputs, economical and financial data obtained after a face-to-face interview conducted between December 2010 and March 2011 in 21 farms from Cluj county, one of the six administrative departments that form the North Western Romanian's Development Region. These farms were chosen in a random proportional stratified survey, representing the crops' livestock mixed strata farms. The segmentation procedure considered the high farm heterogeneity and it covers two strata, one being the farm size and the other being represented by the farming type (Groves et al., 2004). The last strata was established accordingly to the European classification of the farm typology (European Commission, 2003). The interview used a structured questionnaire formed by 57 questions, divided in five sections: 5 general questions related to the farm situation (juridical status, altitude, production type etc); 11 specific questions especially designed for family type farms (family description: age, family relationship etc; the implication in agricultural activity; revenues obtained outside the agriculture, etc); 2 questions related to agricultural land disposal and the farm's employees; 17 questions designed to gather data about the farm's assets, investments made in the last five years or the financial resources involved in short and long run farm activity and, 22 questions that cover the farm's production techniques: activities, revenues, costs, subsidies. All these questions permitted to establish the economic farm size expressed in terms of European Size Units (1 ESU = 1200 Euros). Based upon this concept, the farm sample is divided in three groups: the first one is represented by 9 farms that have less than $5 \mathrm{ESU}$, the second one comprises 7 farms that have less than 50 but more than $5 \mathrm{ESU}$ and the last group consists of 5 farms that have more than 50 ESU.

Descriptive statistics shows that all these three farm classes are relatively homogenous in terms of economical size (Tab.1). The first farm group characterises the small semi-subsistence farms having around 14.8 hectares of agricultural land and 8.0 dairy cows on average. The second one characterises the commercial farms that have an average of 84.6 hectares of agricultural land and 25 dairy cows. The last one represents big commercial farms that are very important in terms of physical and economical size.

The individual farm data from these groups, served as a starting point in constructing three farm types based on a weighting system. The economical data that characterise a specific production type such as prices, costs, yields or subsidies were obtained as averages in farms that employed it in the base year. In order to compute the activity level, the individual data were summarized, and then, they were divided by the number of farms from each of the classes. As 
Tab. 1. Farm sample descriptive statistics

\begin{tabular}{|c|c|c|c|c|c|c|c|c|c|c|c|c|}
\hline & \multicolumn{4}{|c|}{$\begin{array}{l}\text { Agricultural land } \\
\text { (ha) }\end{array}$} & \multicolumn{4}{|c|}{$\begin{array}{c}\text { Number of dairy cows } \\
\text { (heads) }\end{array}$} & \multicolumn{4}{|c|}{$\begin{array}{c}\text { Economic size } \\
(\mathrm{ESU})\end{array}$} \\
\hline & Min & Max & Average & St. dev. & Min & $\operatorname{Max}$ & Average & St. dev. & Min & Max & Average & St. dev. \\
\hline$<5 \mathrm{ESU}$ & 6.3 & 33.0 & 14.8 & 8.4 & 3.0 & 20.0 & 8.0 & 5.0 & 1.5 & 4.5 & 3.3 & 1.0 \\
\hline$>5 \mathrm{ESU}<50 \mathrm{ESU}$ & 15.0 & 129.0 & 84.6 & 38.5 & 11.0 & 42.0 & 24.7 & 11.1 & 6.0 & 48.7 & 19.1 & 14.6 \\
\hline$>50 \mathrm{ESU}$ & 122.0 & 394.0 & 230.0 & 100.9 & 28.0 & 90.0 & 50.6 & 24.3 & 69.2 & 139.0 & 90.0 & 28.0 \\
\hline
\end{tabular}

Source: 2011 farm survey results; (St.dev. = standard deviation)

in this case, such a technique is appropriate when all the farms have the same technical orientation, because without an important financial effort, all of them are capable of producing all the agricultural activities that were observed in the based year in the region.
After optimising model (2), results show that for the first farm type, the least attractive output in term of gross margins is triticale, for the second such production is spring barley and once again triticale for the third farm (Tab. 3).

Tab. 2. Farm type description

\begin{tabular}{|c|c|c|c|c|c|c|c|c|c|c|c|c|c|c|}
\hline \multirow{2}{*}{$\begin{array}{l}\text { Farm } \\
\text { type }\end{array}$} & \multicolumn{7}{|c|}{$\begin{array}{l}\text { Field crops } \\
\text { (ha) }\end{array}$} & \multicolumn{3}{|c|}{$\begin{array}{c}\text { Fodder crops } \\
\text { (ha) }\end{array}$} & \multicolumn{2}{|c|}{$\begin{array}{c}\text { Grassland and meadow } \\
\text { (ha) }\end{array}$} & \multicolumn{2}{|c|}{$\begin{array}{c}\text { Livestocks } \\
\text { (heads) }\end{array}$} \\
\hline & Wheat & Corn & Barley & Rye & $\begin{array}{c}\text { Sun } \\
\text { flower }\end{array}$ & & otatoes & Triticale & $\begin{array}{l}\text { Winter } \\
\text { fodder }\end{array}$ & $\begin{array}{l}\text { Corn } \\
\text { silage }\end{array}$ & Grassland & Meadow & $\begin{array}{l}\text { Dairy } \\
\text { cows }\end{array}$ & Calves \\
\hline $\mathrm{x}_{0}$ & 0.94 & 1.11 & 0.84 & 0.06 & 0.56 & & 0.53 & 0.86 & 0.07 & 0.56 & 1.67 & 6.79 & 8.00 & 1 \\
\hline II. & Wheat & Corn & Barley & $\begin{array}{l}\text { Spring } \\
\text { barley }\end{array}$ & $\begin{array}{c}\text { Sun } \\
\text { flower }\end{array}$ & Rape & Potatoes & Clover & $\begin{array}{l}\text { Winter } \\
\text { fodder }\end{array}$ & $\begin{array}{l}\text { Corn } \\
\text { silage }\end{array}$ & Grassland & Meadow & $\begin{array}{l}\text { Dairy } \\
\text { cows }\end{array}$ & Calves \\
\hline $\mathrm{x}_{0}$ & 12.14 & 7.00 & 1.14 & 0.86 & 6.43 & 2.00 & 0.83 & 3.86 & 6.57 & 11.29 & 48.43 & 5.71 & 25.00 & 8.00 \\
\hline III & Wheat & Corn & Barley & Oat & $\begin{array}{c}\text { Sun } \\
\text { flower }\end{array}$ & Rape & $\begin{array}{c}\text { Sugar } \\
\text { beet }\end{array}$ & Triticale & -.- & $\begin{array}{l}\text { Corn } \\
\text { silage }\end{array}$ & Grassland & -.- & $\begin{array}{l}\text { Dairy } \\
\text { cows }\end{array}$ & Calves \\
\hline$x_{0}$ & 38 & 27 & 13 & 3 & 19.5 & 18 & 26.3 & 23 & --. & 49.25 & 20.5 & -.. & 51 & 13 \\
\hline
\end{tabular}

Source: own results

The first agricultural farm type (I in Tab. 2) produces as field crops those activities that are important for the family subsistence as potatoes, wheat or corn. The arable area allocated to these productions is relatively small. For animal feeding in the first farm type the fodder crops are less employed, as compared with grasslands and meadows, which are used in larger scale due to the less capital intensive demands. In comparison, the third farm type (III) devotes important arable area to field crops. Meanwhile, fodder crops are important in animal feeding.
So, these three crops were cultivated only due to the farmer's risk aversion (the first farmer type gave up to 541 Euros when in 2010 he decided to produce triticale instead of potatoes). These production plans, even if they were less effective, would have met the risk level that the farmers were ready to undertake (Howitt, 1995). With these opportunity costs $(\lambda 2 i)$ (Tab. 3 ), and the equations $\delta i=\lambda 2 i /$ pixi* and $\beta i=q i+\delta i x i^{*}$, the yield function parameters can be calculated (De Frahan et al., 2007).

Tab. 3. The opportunity cost paid in 2010 by the farmers (Euros)

\begin{tabular}{|c|c|c|c|c|c|c|c|c|c|c|c|c|c|c|}
\hline \multirow{2}{*}{$\begin{array}{c}\begin{array}{c}\text { Farm } \\
\text { type }\end{array} \\
\text { I. }\end{array}$} & \multicolumn{7}{|c|}{ Field crops } & \multicolumn{3}{|c|}{ Fodder crops } & \multicolumn{2}{|c|}{$\begin{array}{c}\text { Grassland and } \\
\text { meadow }\end{array}$} & \multicolumn{2}{|c|}{ Livestocks } \\
\hline & Wheat & Corn & Barley & Rye & $\begin{array}{c}\text { Sun } \\
\text { flower }\end{array}$ & & & Triticale & $\begin{array}{l}\text { Winter } \\
\text { fodder }\end{array}$ & $\begin{array}{l}\text { Corn } \\
\text { silage }\end{array}$ & Grassland & Meadow & $\begin{array}{l}\text { Dairy } \\
\text { cows }\end{array}$ & Calves \\
\hline$\lambda_{2 \mathrm{i}}$ & 41.9 & 88.1 & 34.3 & 36.9 & 75.0 & & 1.0 & 0.0 & 37.6 & 330.9 & 18.6 & 39.3 & 427.4 & 352.6 \\
\hline II. & Wheat & Corn & Barley & $\begin{array}{l}\text { Spring } \\
\text { barley }\end{array}$ & $\begin{array}{c}\text { Sun } \\
\text { flower }\end{array}$ & Rape & Potatoes & Clover & $\begin{array}{l}\text { Winter } \\
\text { fodder }\end{array}$ & $\begin{array}{l}\text { Corn } \\
\text { silage }\end{array}$ & Grassland & Meadow & $\begin{array}{l}\text { Dairy } \\
\text { cows }\end{array}$ & Calves \\
\hline$\lambda_{2 \mathrm{i}}$ & 67.1 & 209.8 & 10.0 & 0.0 & 2,1 & 85.8 & 766.2 & 41.6 & 15.6 & 296.3 & 24.2 & 50.7 & 401.9 & 13.8 \\
\hline III & Wheat & Corn & Barley & Oat & $\begin{array}{c}\text { Sun } \\
\text { flower }\end{array}$ & Rape & $\begin{array}{l}\text { Sugar } \\
\text { beet }\end{array}$ & Triticale & --- & $\begin{array}{l}\text { Corn } \\
\text { silage }\end{array}$ & Grassland & -.- & $\begin{array}{l}\text { Dairy } \\
\text { cows }\end{array}$ & Calves \\
\hline$\lambda_{2 \mathrm{i}}$ & 301.6 & 868.1 & 111.9 & 12.4 & 428.1 & 439.3 & 2686.6 & 0.0 &.-- & 159.7 & 8.8 & --- & 299.5 & 40.7 \\
\hline
\end{tabular}

Source: own results (MatLab 7.1 solver); ---- not cultivated; the average exchange rate in 2010 was 4.2 lei/Euros 
The resulted behaviour parameters (Tab. 4) were used later on in the construction of model (3). It simultaneously optimises the production pattern, production techniques, investments level, contracted credits and capital placements. Moreover, the objective function maximises the net income for each farm type it being defined as the difference between the commercial output value and the total production costs. In the model, i represents different types of crops; $\mathrm{t}$ : year of optimisation; $\mathrm{p}_{\mathrm{i}, \mathrm{r}}$ : price per unit of "i" production (unit of measurement - u.m./tone); $\delta$ and $\beta_{\mathrm{i}}$ : behavioural parameters of the yield function; $x_{i, t}$ : the level of the " $i$ " production (ha or heads); $p_{r .}$ : unit price for the least attractive output; $\mathrm{q}_{\mathrm{rtr}}$ : average yield obtained in the least favourable production; $\mathrm{CMV}_{\text {i. }}$ : average variable cost for yielding one "i" output unit (u.m./ha or u.m/ head); INTPAY: interest paid to obtain (short or long terms) loans (u.m.); INTRECU $U_{t}$ interests obtained after investing the available cash-flow (u.m.); CHARGI: general administration costs (u.m.); AMORTI: amortisation costs (u.m.); INVAMORTI $I_{r}$ investments made in the reference year (u.m.); $\mathrm{H}_{\text {suplim } \mathrm{e}}$ : supplementary working hours needed in the farm (based on the seasonal market); $\mathrm{PH}_{t}$ : tariff of an extra working hour (calculated on the basis of the average income in Romania); FVI: owned land surface (ha); PMT: the arable land shadow prices (u.m./ha), calculated by the model's dual; $\mathrm{FER}_{\text {suplim }}$ : leasable arable land (ha); $\operatorname{Pr}_{\text {fer }}:$ rental per hectare (u.m./ha) (for the reference year, the rental corresponds to the real expenses paid by the farmer; for the following years it is proportional to the land opportunity cost); $\mathrm{B}_{\text {forage }}$ : the amount of forage bought if needed in the " $\mathrm{t}$ th" year $\left(\operatorname{Pr}_{\text {forage }}\right.$ : forage price unit);

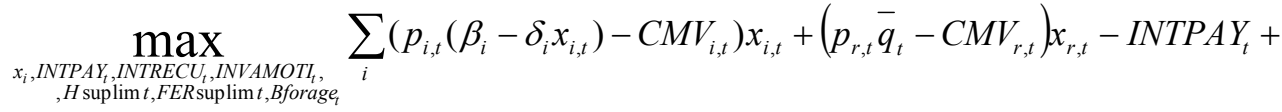

$$
\begin{aligned}
& + \text { INTRECU }_{t}-\text { CHARGI }_{t}-\text { AMORTI }_{t}-\text { INVAMORTI }_{t}-H_{\text {suplim } t} P H_{t} \\
& -F V I_{t} * P M T_{t}-F E R_{\text {suplim } t} * \operatorname{Pr}_{\text {fert }}-\text { Bforage } e_{t} * \operatorname{Pr}_{\text {forage }}
\end{aligned}
$$

\section{Subject to :}

$$
\begin{aligned}
& \left(i_{1}\right) \sum_{i} x_{i, t} \leq H A I_{t}+A C T E R R E_{t}+F E R_{\text {suplim } t} \\
& \left(i_{2}\right) \sum_{i} a_{i} x_{i, t} \leq D I S P O_{t}+H_{\text {suplim }} ; \\
& \left(i_{3}\right) \sum_{i} x_{c c_{i}, t} \leq 2 x_{c m} \\
& \left(i_{4}\right) \sum_{i} x_{a_{i}, t} \leq \text { Forages }_{t}+\text { Bforage; } \\
& \left(i i_{1}\right) T R E Z_{t-1} \geq C H A R G t_{t}^{E X P L}+C H A R G I_{t}^{S A L}+C H A R G I_{t}^{I N V}+P L A C E M_{t}-\text { REVENUE }_{-} \text {CREDITS; } \\
& \left(i_{2}\right) \operatorname{TREZ}_{t}=\operatorname{TREZ}_{t-1}+\sum_{i} \text { MARGE }_{t, i}+\text { TotalCredits }_{t}-\text { Annuites }_{t} \\
& \left(i i i_{1}\right) \sum_{m} L O N C R E D_{P R O D} \leq M A X C R E D_{P R O D} \text {; } \\
& \text { (iii } \left.)_{2}\right) \operatorname{TREZ}_{t-1}=\text { SURPLUS }_{t}+\text { COUTS }_{\text {prod }} \text {; } \\
& \text { (iii } \left.i_{3}\right) \text { LONCRED }_{I N V t}+\text { AUTOFIN }_{t}=I N V_{t} ; \\
& \text { (iii } \left.i_{4}\right) L O N C R E D_{I N N t} \leq M A X C R E D_{I N V} \text {; } \\
& \left(\text { iii }_{5}\right) \text { SURPLUS }_{t}=\text { PLACEM }_{t}+\text { AUTOFIN }_{t} \text {; }
\end{aligned}
$$


Tab. 4. The yield function parameters

\begin{tabular}{|c|c|c|c|c|c|c|c|c|c|c|c|c|c|c|}
\hline \multirow{2}{*}{$\begin{array}{c}\text { Farm type } \\
\text { I. }\end{array}$} & \multicolumn{7}{|c|}{ Field crops } & \multicolumn{3}{|c|}{ Fodder crops } & \multicolumn{2}{|c|}{ Grassland and meadow } & \multicolumn{2}{|c|}{ Livestocks } \\
\hline & Wheat & Corn & Barley & Rye & $\begin{array}{c}\text { Sun } \\
\text { flower }\end{array}$ & & otatoes & Triticale & $\begin{array}{l}\text { Winter } \\
\text { fodder }\end{array}$ & $\begin{array}{l}\text { Corn } \\
\text { silage }\end{array}$ & Grassland & Meadow & $\begin{array}{l}\text { Dairy } \\
\text { cows }\end{array}$ & Calves \\
\hline$\delta_{i}$ & 0.61 & 1.11 & 0.61 & 9.56 & 1.25 & & 4.88 & 0.00 & 8.06 & 11.28 & 11.28 & 0.29 & 162.56 & 131.66 \\
\hline$\beta_{i}$ & 2.8 & 5.2 & 2.3 & 2.1 & 2.9 & & 6.6 & 2.4 & 3.2 & 16.3 & 4.8 & 4 & 4093.8 & 316.7 \\
\hline II. & Wheat & Corn & Barley & $\begin{array}{l}\text { Spring } \\
\text { barley }\end{array}$ & $\begin{array}{c}\text { Sun } \\
\text { flower }\end{array}$ & Rape & Potatoes & Clover & $\begin{array}{l}\text { Winter } \\
\text { fodder }\end{array}$ & $\begin{array}{l}\text { Corn } \\
\text { silage }\end{array}$ & Grassland & Meadow & $\begin{array}{c}\text { Dairy } \\
\text { cows }\end{array}$ & Calves \\
\hline$\delta$ & 0.05 & 0.29 & 0.13 & 0.00 & 0.003 & 0.37 & 12.32 & 0.19 & 0.04 & 0.92 & 0.01 & 0.16 & 45.01 & 0.01 \\
\hline$\beta_{i}$ & 3.6 & 6.9 & 1.9 & 2.2 & 2.4 & 3.3 & 9.1 & 6.7 & 3.8 & 3.0 & 3.8 & 4.4 & 4846.8 & 1.1 \\
\hline III & Wheat & Corn & Barley & Oat & $\begin{array}{c}\text { Sun } \\
\text { flower }\end{array}$ & Rape & $\begin{array}{c}\text { Sugar } \\
\text { beet }\end{array}$ & Triticale & -.- & $\begin{array}{l}\text { Corn } \\
\text { silage }\end{array}$ & Grassland & --- & $\begin{array}{l}\text { Dairy } \\
\text { cows }\end{array}$ & Calves \\
\hline$\delta$ & 0.05 & 0.18 & 0.06 & 0.03 & 0.05 & 0.08 & 0.77 & 0.00 & --- & 0.11 & 0.01 & -.- & 17.27 & 0.01 \\
\hline$\beta_{i}$ & 6.6 & 12 & 5.2 & 3.7 & 3.2 & 4.2 & 49.5 & 4 & --- & 24.6 & 4.3 & -- & 5530.1 & 1.3 \\
\hline
\end{tabular}

Source: own results (MatLab 7.1 solver); ---- not cultivated;

The economic and mathematical programming models represents in a simplified way the operating mode of a farm (Hazel and Norton, 1986). Thus, the constraints' system needs to simulate the real conditions on which a farmer basis his decisions.

In this model, multiple types of constraints were introduced. The first type is represented by constraints simulating the factorial resources, like: $\left(i_{1}\right)$ available arable land: the cultivated surface within a year cannot exceed the area in property $\left(\mathrm{HAI}_{\mathrm{r}}\right)$ plus rented $\left(\mathrm{FER}_{\text {suplim } t)}\right.$ and bought land (ACTERRE); $\left(i_{2}\right)$ available labour force: the necessary labour time to organise the optimal crop rotation $\left(a_{i}\right)$ cannot exceed the permanent working force (family or hired full time labour) (DISPO) to which seasonal labour can be added $\left(\mathrm{H}_{\text {suplim } \mathrm{t}}\right) ;\left(\mathrm{i}_{3}\right)$ and $\left(\mathrm{i}_{4}\right)$ means specific agronomical requirements. As the farms' typology is mixed crops livestock, the model imposed a three-year crops rotation corn $\left(\mathrm{x}_{\mathrm{cm}}\right)$ - other crops $\left(\mathrm{x}_{\mathrm{ccr}}\right)$ and a forage balance in which the forage can be supplied either from own production Forages ${ }_{\mathrm{t}}$ or from buying in Bforage,

Treasury constraints: (ii ${ }_{1}$ ) operational cash position balance that state the balance between the farm's cash flows in and out. In order to ensure an optimal treasury management, the farmer has to fill in the gap between obtaining the production counter balance and paying his legal duties (salaries, taxes, payments) enhanced with possible annual payments (annuities for the obtained loans). The available data, did not allow to build a financial monthly equation of this constraint. Still, a yearly operational financial constraint has been built. The needed operational capital represents the entire production cost encountered from the moment of starting the production to harvesting (CHARGI ${ }_{r}^{\text {EXPL }}$; CHARGI ${ }_{t}^{\text {SAL }}$ ) and the investments $\left(\mathrm{CHARGI} I_{t}^{\mathrm{INV}}\right)^{2}$. The operational capital resources are represented by the starting-period cash $\left(\mathrm{TREZ}_{\mathrm{i}-1)}\right.$, the short-term loans (CREDITS $)$ and the production's revenue $\left(\right.$ REVENUE $\left._{\mathrm{t}}\right) ;\left(\mathrm{ii}_{2}\right)$ cash position at the end of year:
(TREZ) is equal to the sum between last year end liquid assets $\left(\right.$ TREZ $\left._{\mathrm{t}-1}\right)$, the yearly gross margins $\left(\sum\right.$ MARGE $\left._{t, i}\right)$ and the loans ( TotalCredits ${ }_{\mathrm{t}}$ ) minus the current year annuities (Annuities);

If the financing possibilities were unlimited, the farmer would be interested in capital investments for a short period of time (by immobilising it in the present production) or by making long-term capital investments, taking into consideration the agricultural constant return to scale hypothesis (Caves et al., 1982). However, these kind of external financial resources are incredibly limited because agriculture is perceived to be a risky activity. Moreover, the bankers would rather prefer bigger farms that can provide better collaterals in receiving loans. Based on these observations, farm development is limited to the capital level that they can attract. Consequently, the following types of financial constraints were used: $\left(\mathrm{iii}_{1}\right)$ financing production needs: stands for overcoming the gap between paying the duties (payments for agricultural inputs, payments of salaries; payments of legal duties) and the money received (the production value) smaller at a certain time. This temporary shortcoming has to be financed from external resources. These are represented by short term bank loans (LONCRED ${ }_{\text {PROD m })}$. The level of short term bank loans (MAXCRED PROD $^{\text {m }}$ ) must not exceed a certain level established by the bank. In its definition, the legal issues have been taken into consideration. The Romanian law $311 / 2001$ (agricultural credit law), states that when contracting such loans, the Romanian state through the Rural Credit Warranty Fund, guarantees $80 \%$ of the contracted loan volume. Based on this information, it is most likely that the banks will give loans solely if the liquid assets of the agricultural farm represent $20 \%$ of the required loan; $\left(\mathrm{iii}_{2}\right.$ ) financing investments: the decision for an investment requires a financial commitment taken on several years. The Johnson theory regarding the capital immobilisations says that they have a fixed value over a short period 
of time (Happe, 2004). That is why their supplementary depreciation must be part of the objective function, and the model accepts an investment only if the annual income value growth is higher than the depreciation rate and the financial spending in case of contracting long-term investments loans. In order to simulate these constraints, several equations have been used. The first establishes the available financial resources after covering the production spending $\left(\right.$ SURPLUS $_{\mathrm{r}}$ ), resources that the farmer can decide to use for new investments in short-term capital investments $\left(\right.$ PLACEM $_{\mathrm{t}}$ ) or long-term investments (AUTOFIN $\left.{ }_{\mathrm{t}}\right)$. In financing the investments, the model takes into account that their value (INV) cannot exceed the volume of financial resources available in the farm (AUTOFIN ${ }_{t}$ ) to which can be added long run loans (LONCRED INV $_{t}$. The maximum level of borrowings was established in the model in an exogenous mode $\left(\right.$ MAXCRED $\left._{\text {INV }_{\mathrm{t}}}\right)$.

Other financial information mainly refers to the farm's financial spending of. These costs are due to the short and long-term farm credits. The financial spending for the contracted loans is optimised by the model regarding their moment of contracting and their level. For the long- term credits, the constant annuities reimbursement system was used. The rate of interest is the same as the one on the Romanian capital market. For the short-term credits, the interest rate was 17\% (an observed average in 2010), and for long-term ones $12 \%$. Moreover, for capital investments, a rate of $9 \%$ interest was considered.

\section{Results and discussion}

The official statistical data show that $30 \%$ of the Romanian active population worked in 2009 in agriculture and had a contribution of only $11.6 \%$ in the Gross Domestic Product (GDP). In this meaning, Transylvania produced
$24.7 \%$ of the Romanian GDP and its agriculture had around $26.8 \%$ contribution in the Romanian agricultural net added value. Moreover, the arable land in this area covers $1,793,970.58$ hectares $(16.71 \%$ of the total Romanian resource): $57.8 \%$ are used for cereals, $5.8 \%$ for potatoes and $5.6 \%$ for oil plants (Romanian National Institute of Statistics, 2009).

Based upon these considerations, an important CAP reform can greatly influence the future development pattern of the Romanian economy. The scenarios of the new reforms (post 2013) have been already presented in a recent European Commission proposal (2010):

- Scenario 1: a status-quo approach based upon the current CAP developments (maintains the current payment system but slightly reduces the subsidies value in nominal terms; simplify the payment system and reduce the CAP budget);

- Scenario 2: a moderate reform in which both CAP pillars would be maintained, while the CAP instruments shall be adapted to new agricultural and economical conditions. In such a scenario, the second pillar will be reinforced whereas to better respond to new CAP challenges such as climate changes, water management and biodiversity. The direct payment will be composed of a basic amount serving as income support and additional payments to compensate specific natural constraints of green public services. In order to find the basic amount that will not decrease the farm revenue, two options were further investigated. In the first one, it is assumed that for every activity unit applied in the farm, the subsidy will equal 100 Euros. Subsidy level is equal to 200 Euros in the second investigated option.

- Scenario 3: a radical reform in order to state the total liberalisation of the European agri-food commerce. In this case, only the second CAP pillar will be maintained and

Tab. 5. The average gross margin per hectare after the CAP reform scenarios evaluation

\begin{tabular}{|c|c|c|c|c|c|c|c|}
\hline Scenarios & 2010 & 2011 & 2012 & 2013 & 2014 & 2015 & 2016 \\
\hline \multicolumn{8}{|c|}{ Farm type I (Euros/ hectare) } \\
\hline I & 579.62 & 625.68 & 672.35 & 717.98 & 765.83 & 814.26 & 863.32 \\
\hline II.01 & 579.62 & 625.68 & 672.35 & 717.98 & 566.28 & 577.01 & 581.30 \\
\hline II.02 & 579.62 & 625.68 & 672.35 & 717.98 & 740.18 & 742.17 & 742.60 \\
\hline III & 579.62 & 625.68 & 672.35 & 717.98 & 400.09 & 401.54 & 403.26 \\
\hline \multicolumn{8}{|c|}{ Farm type II (Euros/ hectare) } \\
\hline I & 262.69 & 289.82 & 317.15 & 343.76 & 371.41 & 399.25 & 427.27 \\
\hline II.01 & 262.69 & 289.82 & 317.15 & 343.76 & 257.10 & 257.49 & 259.02 \\
\hline II.02 & 262.69 & 289.82 & 317.15 & 343.76 & 361.29 & 362.14 & 363.29 \\
\hline III & 262.69 & 289.82 & 317.15 & 343.76 & 155.20 & 155.91 & 158.41 \\
\hline \multicolumn{8}{|c|}{ Farm type III (Euros / hectare) } \\
\hline I & 758.18 & 790.21 & 822.51 & 854.21 & 887.05 & 920.18 & 953.58 \\
\hline II.01 & 758.18 & 790.21 & 822.51 & 854.21 & 751.72 & 752.60 & 753.50 \\
\hline II.02 & 758.18 & 790.21 & 822.51 & 854.21 & 874.78 & 875.45 & 876.49 \\
\hline III & 758.18 & 790.21 & 822.51 & 854.21 & 632.21 & 632.82 & 643.46 \\
\hline
\end{tabular}

Source: own results (MatLab 7.1 solver) 
132

the farmer will receive payments only after fulfilling important cross compliance rules while the direct payments will be gradually phased-out. In this scenario, it is assumed that farmers received no subsidies in the first CAP pillar.

The level of the financial support given to Romanian farmers after 2013 (the new CAP reform) represents an important element which shall influence especially the way in which they build the production decisions (Tab. 5). The impact of the financial subsidies on the average gross margin per hectare can be analysed for each farm type in different scenarios.

The evolution of the average forecasted gross margin per hectare has almost the same evolution in all three-farm types. In the status-quo scenario, the average gross margin per hectare increases between 2013 - 2016 with around $20 \%$ (first farm type), 24\% (the second) and $11 \%$ (the third farm type). This evolution is linked to the fact that for that period, the direct subsidy per agricultural activity unit is anticipated to increase $10 \%$ per year in order to align it to the European level. Practically, in 2016, the Romanian farms will receive the same subsidy level as in the other EU member states. Furthermore, in this case, the payments are still linked to the farm size that means that the smaller farm will get fewer subsidies in nominal terms as compared to the bigger one.

When, in the second scenario, the basic amount per agricultural unit equals 100 Euros (II.01) the average gross margin per hectare decreases with around $21 \%$ in the first farm type, with $25 \%$ in the second and only with $12 \%$ in the third farm type. These results show the fact that without good agricultural policy measures in the second CAP pillar, the smallest farms in terms of physical and economical size probably will suffer greater financial losses. A basic subsidy amount of 200 Euros per agricultural unit (II.02) will sustain the farm's revenue as before the reform. In this case, other subsidies schemes linked to any societal cross compliance rules allocated through the second CAP pillar can further improve the farm's revenue.

The third scenario means a greater loss of average gross margin for the analysed farms. Practically, such an agricultural policy produces important economical effects. The average gross margin per hectare decrease with $44 \%$ in the first farm type, $55 \%$ in the second one and with only $25 \%$ in the third farm type. In order to avoid the financial destabilisation of the smallest farm in term of economical size a "soft landing" approach, in terms of agricultural policy is desirable. It is represented by the second policy option that can offer important freedoms to Member States in establishing cross compliance measures that can bring potential societal benefits.

\section{Conclusions}

To summarise, there was proposed an adequate tool for simulating the CAP impact for the Romanian production system. The model is a mono-periodical recursive one, which optimizes in the same time: the production pattern, the financial resources, the investment possibilities and the agricultural policy measures. Moreover, the model was applied on 21 Transylvanian farms using relevant agricultural policy scenarios. Results show that the new CAP reform (envisaged after 2013) might produce important consequences in terms of farm revenue variability. Their effects depend on the applied policy tools. A radical first CAP pillar's reform, without a sound rural development programme will greatly affect the farms' revenue. In order to prevent important variations of farm revenues, "soft" reforms measures in the first CAP pillar together with the reinforcement of the second one represent a desirable policy strategy.

\section{Aknowledgements}

This research is part of a scientific project financed by the Romanian National Council of Scientific Research (post doctoral fellows PN II-project number 190/2010).

\section{References}

Arfini F, Brasili Cristina, Fanfani F, Mazzocchi M, Montresor Elisa, Paris Q (2001). Tools for evaluating EU agricultural policies: an integrated approach. Statistical Methods and Applications 10:191-210.

Buysse J, Fernagut B, Harmignie O, Frahan BH, Lauwers L, Polome P, Van Huylenbroeck G, Van Meensel J (2007). Farm based modelling of the EU sugar reform: impact on Belgian sugar beet suppliers. European Review of Agricultural Economics 34(1):21-52.

De Cara S, Houze M, Jayet PA (2005). Methane and nitrous oxide emission from agriculture in the EU: a spatial assessment of sources and abatement costs. Environmental and Resource Economics 32(4):551-583.

Caves DW, Christensen LR, Diewert WE (1982). The economic theory of index numbers and the measurement of input, output, and productivity. Econometrica 50:1393-1414.

De Frahan HB, Buysse J, Polome P, Fernagut B, Harmignie O, Lauwers L, Van Huylenbroeck G, Van Meensel J (2007). Positive mathematical programming for agricultural and environmental policy analysis: review and practice, p. 124154. In: Handbook of Operations Research in Natural Resources. Springer, USA.

European Commission (2003). Commission decision of 16 May 2003 amending Decision 85/377/EEC establishing a Community typology for agricultural holdings (2003/369/ EC). European Commission, Brusseles.

European Commission (2010). Communication from the Commission to the European Parliament, the Council, the European Economic and Social Committee and the Committee of the Regions-the CAP towards 2020: meeting the food, natural resources and territorial challenges of the future. European Commission, Brusseles.

Gary C, Jones JW, Tchamitchian M (1998). Crop modelling in 
horticulture: state of the art. Scientia Horticulturae 74(12):3-20.

Groves RM, Fowler RM, Couper FJ, Lepkwoski JM, Singer Eleanor, Tourangeau R (2004). Survey methodology. John Wiley and Sons, New Jersey.

Happe Kathrin (2004). Agricultural policies and farm structures: agent-based modelling and application to EU policy reform. University of Hohenheim, Halle, Germany, PhD Diss. Abstr. 1-267.

Hazel PBR, Norton RD (1986). Mathematical programming for economics analysis in agriculture. Macmillan Publishing Company, New York.

Hester Susan, Cacho J (2003). Modelling apple orchard systems. Agricultural Systems 77(2):137-154.

Howitt RE (1995). A calibration method for agricultural economic production models. Journal of Agricultural Economics 46(2):147-159.

Howitt RE (2005). PMP based production models-development and integration. Proc. the $\mathrm{XI}^{\text {th }}$ EAAE Congress: the future of rural Europe in the global agri-food system. Denmark, Copenhagen.
Judez L, De Miguel JM (2002). Modelling crop regiona production using positive mathematical programming. Mathematical and Computer Modelling 35(1-2):77-86.

Lentz W (1998). Model applications in horticulture: a review. Scientia Horticulturae 74(1-2):151-174.

Romanian National Institute of Statistics (2009). Romanian Statistical Yearbook. Romanian National Institute of Statistics, Bucharest.

Veysset P, Bebin D, Lherm M (2005). Adaptation to Agenda 2000 (CAP reform) and optimisation of the farming system of French suckler cattle farms in the Charolais area: a modelbased study. Agricultural Systems 83:179-202.

Vinten AJA, Dunn SM (2001). Assessing the effects of land use on temporal change in well water quality in a designated nitrate vulnerable zone. The Science of the Total Environment 265(1-3):253-268. 